\title{
PENGARUH EKSTRAK DAUN KERSEN (Muntingiacalabura I.) TERHADAP GAMBARAN HISTOPATOLOGI HEPAR PADA MENCIT (Mus musculus) YANG DIINDUKSI DIET TINGGI LEMAK
}

\author{
Muchamad Fadil ${ }^{1}$, Sulistyo Mulyo Agustini ${ }^{2}$, Bragastio Sidharta $^{3}$ \\ Fakultas Kedokteran, Universitas Muhammadiyah Malang \\ J1. BendunganSutami 188 A Malang, 65145
}

Email : Muchamadfadil73@gmail.com

\begin{abstract}
ABSTRAK
Dislipidemia merupakan faktor yang paling sering menyebabkan penyakit perlemakan hepar non alkoholik.Daun kersen (Muntingia calabura l.)mengandungantioksidanberupa flavonoid, saponindan tannin yang dapat menghambat stres oksidatif.Tujuan penelitian iniuntukmengetahuipengaruhekstrakdaun kersen (Muntingia calabura l.) terhadapgambaran histopatologi hepar pada mencit yang diinduksi diet tinggi lemak. Metode yang digunakan adalah True experimental denganpost test only control group design. Sampeldibagidalam5kelompok yaitu kelompok kontrol negatif (K1), kontrol positif (K2), dan 3 kelompok perlakuan yang diberi ekstrak daun kersen (Muntingia calabura l.)dengan dosis 1,5mg/20gBB/hari (K3), $3 \mathrm{mg}$ / $20 \mathrm{gBB} /$ hari (K4), $6 \mathrm{mg} / 20 \mathrm{gBB} /$ hari (K5). Data dianalisismenggunakanujionewayanova, ujipost hocbonferroni, danujiregresi linier...Hasilpenelitianmenunjukkan bahwahasilujione way anovadidapatkanpengaruh yang bermakna $(p<0,05)$. Hasil uji one way anovadidapatkan perbedaan yang bermakna antara kelompok kontrol positif dengan kelompok perlakuan $(\mathrm{p}<0,05)$. Hasilujiposthoc bonferronididapatkanperbedaanbermakna $(\mathrm{p}<0,05)$ antara masing-masing perlakuan dengankelompokkontrol. Hasilujiregresi linier didapatkanadjusted $\mathrm{R}^{2}=0,511$ yang menunjukkanbahwaekstrakdaunkersenmemberikanpengaruhsebesar $51 \%$. Pada penelitian ini kelompok perlakuan ekstrak daun kersen dosis $6 \mathrm{mg} / 20 \mathrm{gBB} /$ hari memberikan efek perbaikan gambaran histopatologi yang paling baik. Pada penelitian ini disimpulkan pemberianekstrakdaunkersen berpengaruh terhadap perbaikan gambaran histopatologi hepar pada mencit yang diinduksi diet tinggi lemak
\end{abstract}

Kata kunci : perlemakanhati non alkoholik, ekstrakdaunkersen, diet tinggi lemak, antioksidan.

\begin{abstract}
Dislipidemia is the often factor that caused non alcoholic fatty liver disease. The leaves of kersen (Muntingia calabura l.) contain antioxidant such as flavonoid, saponin, and tannin that can prevent from oxidative stress. Objective of this experiment to find out the effect ofkersen (Muntingia calabura l.) leaves extract on the liver histopatology in rat (Mus musculus) with bigh fat diet.The method of this experiment is true experimental with post-test only control group design. The samples were divided into 5 groups there were controlnegative group (K1), control positive group (K2), 3 groups were given kersen (Muntingia calabura l.) leaves extracts at dose 1,5mg/20gBB/day (K3), 3mg/20gBB/day (K4), 6mg/20gBB/day (K5). Data was analized using onewayanova test, posthocbonferroni test, and linier regression test. The one way anova test results showedthe significant different among control positive group with group of treatment ( $p<0.05)$. Results of post hoc test was found significant of differences $(p<0.05)$ in each group of treatment and control group. The results of linear regression was obtained as adjusted $\mathrm{R}^{2}=0,511$, this shows the effect of kersen (Muntingia calabura l.) leaves extractwas 51\%. In this experiment, group of treatment that given kersen (Muntingia calabura l.) at dose $6 \mathrm{mg} / 20 \mathrm{gBB} /$ day give the best improvement effect on the picture of liver histopathology. Conclusion of this experiment the given of kersen (Muntingia calabura l.) leaves extract influence on the picture ofliverbistopatology inrat (Mus musculus) with high fat diet.
\end{abstract}

Key Words : Non alcoholic fatty liver disease, kersen (Muntingia calabura l.) leaves extract, high fat diet, antioxidant 


\section{PENDAHULUAN}

Non alcoholic fatty liver disease (NAFLD) adalah penumpukan lemak di dalam hepatosit yang melebihi 5\% dari massahepar tanpa adanya asupan etanol yang berlebihan (McCance KL, Huether SE, Brashers VL, Rote NS, 2010). Perlemakan hepar non alkoholik merupakan keadaan yang paling sering menyebabkan penyakit hepar kronis yang dimulai dari steatosis sederhana, steatohepatitis, hingga terjadinya sirosis hepatis (Fatbolcu, Hakan and Zorlu, Elcin, 2016).

Prevalensi perlemakan hepar non alkoholik di Indonesia sebesar 30,6\% ${ }^{3}$.Prevalensi perlemakan heparsebanding dengan peningkatan usia, dengan insidensi tertinggi laki-laki usia 40 sampai dengan 65 tahun. Penyebab utama peningkatan prevalensi perlemakan hepar adalah faktor metabolik seperti obesitas, diabetes melitus tipe II, dislipidemia dan hipertensi arterial. NAFLD merupakan hasil akumulasi dari adanya 'two hit yang dimulai dari akumulasi trigliserida sebagai 'first hit' kemudian terjadi stres oksidatif sebagai 'second hit' yang menyebabkan terjadinya inflamasi, fibrosis, dan nekrosis (Fatbolcu, Hakan and Zorlu, Elcin, 2016) Keadaan ini mendorong kebutuhan tubuh manusia akan antioksidan yang lebih banyak untuk melawan radikal bebas, sehingga dibutuhkan asupan antioksidan dari luar tubuh.

Daun Kersen merupakantanaman obat yang telah terbukti memiliki beberapa manfaat seperti obat antinociceptive (Takahashi Y, Fukusato T, 2014). Daun kersen mengandung beberapa antioksidan seperti flavonoid, tanin, dan saponin (Surjowardojo P, Sarwiyono, Thohari I, Ridhowi A, 2014). Flavonoid pada daun kelor terbukti mencegah perlemakan hepar akibat diet tinggi lemak (Das N, Sikder K, Ghosh S, Fromenty B, Dey S, 2012). Antioksidan pada penelitian efek propolis terhadap perbaikan fungsi hepar menunjukkan adanya perbaikan, dengan cara mempertahankan tingkat intraseluler glutation tereduksi dan scavenging radikal bebas $^{8}$.Berdasarkan penjelasan di atas penulis mencoba melakukan penelitian terkait pengaruhekstrakdaunkersen (Muntingiacalabura l.) terhadapgambaranhistopatologi heparpadamencit (Mus musculus) yang diinduksi diet tinggilemak.

\section{TINJAUAN PUSTAKA}

Makanan yang digoreng dikenal luas karena aroma, rasa dan tekstur yang dihasilkannya. Pada saat makanan digoreng, lemak atau minyak panas akan diserap masuk ke dalam bahan makanan dan menggantikan air yang menguap sehingga bahan makanan menjadi lebih lembut dan tekstur makanan menjadi renyah (Ghidurus, M., Turtoi, M., Boskou, G., Niculita, P., Stan, V., 2010). Deep frying adalah cara memasak atau memanaskan makanan menggunakan minyak dalam jumlah yang banyak, berulang, dan suhu tinggi sekitar $150^{\circ} \mathrm{C}-200^{\circ} \mathrm{C}$ (KrishnaveniMarimuthu, DhanalakshmiRavi, 2014). Selama proses deep frying terjadi berbagai reaksi degradasi, yaitu hidrolisis, oksidasi termal, dan polimerisasi minyak goreng. Indikator paling mudah untuk mengetahui minyak jelantah adalah warnanya coklat tua sampai hitam, terlalu banyak asap, bau tengik, menjadi lebih kental atau timbulnya buih pada minyak saat digunakan (Sartika, R.A.D, 2009, Budiyanto, Zuki Meizul, Hutasoit S. Mina, 2012). Minyak yang telah rusak dan menjadi jelantah tidak hanya memberikan efek negatif pada tekstur, rasa dan gizi makanan yang dihasilkan tetapi juga berdampak buruk bagi kesehatan (Budiyanto, Zuki Meizul, Hutasoit S. Mina, 2012).

Non alkoholic fatty liver disease atau yang dikenal sebagai penyakit perlemakan hepar non alkoholik (PPHNA) adalah akumulasi lipid di dalam hepatosit yang melebihi 5\% dari berat hepar tanpa adanya asupan etanol yang berlebihan (secara konvensional didefinisikan 20g/hari) dan tanpa penyebab penyakit hepar lain. Perlemakan hepar non alkoholik menjadi istilah yang sering digunakan mengacu kepada spektrum luas dari kerusakan hepar, dimulai darigangguan hepar yang ditandai oleh mikrovascular lemak hepar saja disebut dengansteatosis sederhana atau bisa disertai dengan tanda-tanda cedera hepatosit, infiltrasi sel radang campuran, dan variabel fibrosis hepar yang disebut dengansteatohepatitis non alkoholik (SHNA). Steatohepatitis non alkoholik dapat menyebabkan sirosis dan karsinoma hepatoseluler.

Teori kejadian PPHNA didasari oleh 'two hit hipotesis'. 'First hit'berupa akumulasi trigliserida di hepatik disebut dengan steatosis, sedangkan peningkatan kerentanan hepar untuk mengalami cedera dimediasi oleh 'second hit'seperti sitokin inflamasi atau adipokin, disfungsi dari mitokondria dan stres oksidatif yang dapat menyebabkan 
steatohepatitis atau fibrosis. Namun, peningkatan asam lemak bebas juga berperan secara langsung terhadap kejadian cedera hepar, menyebabkan modifikasi teori ini (Castilla P, Echarri R, Davalos A, Cerrato F, 2006).

Pada kejadian obesitas dan resistensi insulin terjadi peningkatan masukan asam lemak bebas ke hepar. Asam lemak bebas ini mengalami â-oksidasi atau esterifikasi dengan gliserol membentuk trigliserida yang mengakibatkan penumpukan lemak di hepar. Namun sekarang telah dibuktikan bahwa substansi dari asam lemak bebas secara langsung dapat menyebabkan efek toksik dengan cara meningkatkan stresoksidatif dan aktivasi jalur inflamasi. Oleh karena itu akumulasi trigliserida di hepar dianggap sebagai mekanisme perlindungan terhadap efek toksik dari asam lemak bebas yang tidak teresterifikasi. (Castilla P, Echarri R, Davalos A, Cerrato F, 2006)

Selanjutnya terdapat komponen tambahan mengenai 'third hit' yaitu mencerminkan regenerasi hepatosit yang tidak adekuat.Pada hepar yang normal, kematian sel menstimulasi replikasi hepatosit yang matur menggantikan sel-sel yang mati dan menyusun kembali fungsi jaringan normal. Namun stres oksidatif merupakan patogenesis utama dalam kejadian perlemakan hepar, dengan menghambat replikasi dari hepatosit yang matur yang menghasilkan perluasan sel progenitor hepar (sel oval). (Castilla P, Echarri R, Davalos A, Cerrato F, 2006)

Pada kejadian cedera hepar kronik, perkembangan fibrosis atau sirosis bergantung dengan kemampuan regenerasi hepatosit, dan oleh karena itu kematiansel dengan gangguan proliferasi hepatosit progenitor diusulkan sebagai 'third hit' di dalam patogenesis PPHNA.

Daun kersen mengandung banyak antioksidan seperti tanin, saponin, flavonoid, dan cathecin. Antioksidan terbanyak dalam daun kersen adalah flavonoid diikuti kadar tannin lalu saponin yang tidak terlalu banyak (Surjowardojo P, Sarwiyono, Thohari I, Ridhowi A, 2014). Dari penelitian didapatkan bahwa kadar antioksidan yang dimiliki daun kersen lebih banyak dari pada kadar antioksidan yang ada pada buah kersen ${ }^{8}$.Flavonoid memiliki peran dalam menurunkan kadar mediator proinflamasi melalui hambatan terhadap nuclearfactor kB (Anggia S.W.J, 2015). Flavonoid sebagai antioksidan secara langsung yaitu dengan mendonorkan ion hidrogen sehingga dapat menetralisir efek toksik dari radikal bebas. dan mekanisme tidak langsung yaitu dengan meningkatkan ekspresi gen antioksidan endogen melalui beberapa mekanisme. Salah satu mekanisme peningkatan ekspresi gen antioksidan adalah melalui aktivasi nuclear erythroid relates factor 2 (Nrf2) sehingga terjadi peningkatan gen yang berperan dalam sintesis enzim antioksidan endogen seperti misalnya gen SOD (superoxide dismutase). (Kumar V, Abbas AK, Aster JC, 2015)

\section{METODE PENELITIAN}

Penelitian true experimental dengan menggunakan metode Post Test Only Control Group Design. Penelitian ini bertempat di Laboratorium Biomedik FK UMM selama 3 minggu. Populasi dan sampel dalam penelitian ini adalahmencit putihjantan (Mus musculus) dengan berat 30-40 gram danberusia 2-3 bulan dengan kondisi sehat yang ditandai dengan gerakan yang aktif dan mata jernih. Peneliti menetapkan kelompok perlakuan terdiri dari 5 kelompok yaitu, satu kelompok kontrol negative $(\mathrm{K}-)$, kontrolpositif $(\mathrm{K}+)$ yaitu hanya diinduksi minyak jelantah, perlakuan 1 induksi minyak jelantah dan ekstrak daun kersen1,5mg/20g/hr (P1), perlakuan 2 minyak jelantah dan ekstrak daun kersen3 mg/20g/hr (P2) dan perlakuan 3minyak jelantah dan ekstrak daun kersen6 mg/20g/hr (P3) dengan masing-masing kelompok terdapat 6 ekor mencit. Mencit diaklimatisasi selama 7 hari dengan diberikan pakan standar BR-1 ditambah air minumad libitum. Selanjutnya, dilakukan pembedahan pada mencit untuk diambil heparnya dan dilakukan pemeriksaan histopatologi. Setelah didapatkan data, kemudian dilakukan analisis dengan uji one way ANOVA, post hoc bonferroni, danujiregresi linier.

\section{HASIL PENELITIAN}

Hasil penelitian ini menunjukkan jumlah rerata selballoning $\mathrm{K}-=0,75 \mathrm{sel}, \mathrm{K}+=8,5 \mathrm{sel}, \mathrm{P} 1=$ 4,5sel, P2 $=4$ sel, dan P3 $=2,75$ sel. Hasiluji one way anovadidapatkan hasil sig $=0,001$ yang berarti adapengaruh yang bermakna $(p<0,05)$. Hasiluji post hoc didapatkanhasil antara kelompok kontrol positif dengan perlakuan terdapat perbedaan yang bermakna $(p<0,05)$. Hasil uji regresi linier didapatkan adjusted $\mathrm{R}^{2}=0,511$ hal tersebut bermakna bahwa pemb erian ekstrak daun kersen memiliki pengaruh 
terhadap gambaran histopatologi pada hepar mencit sebesar $51,1 \%$ dan $48,9 \%$ lainnya dipengaruhi oleh faktor lain yang tidak diteliti.

Pada penelitian ini kelompok perlakuan ekstrak daun kersen dosis $6 \mathrm{mg} / 20 \mathrm{gBB} /$ hari memberikan efek perbaikan gambaran histopatologi yang paling baik

\section{PEMBAHASAN}

Hasil penelitian ini membuktikan bahwa terdapat pengaruh pemberian ekstrak daun kersen terhadap gambaran histopatologi pada hepar mencit yang diinduksi diet tinggi lemak. Hal ini mendukung penelitian tentang efek preventif dari ekstrak daun kelor (Moringaoleiferal.) yang mengalami kerusakan hepar akibat diet tinggi lemak. Penelitian tersebut menggunakan dosis ekstrak daun kelor (Moringaoleiferal.) $0,15 \mathrm{mg} / \mathrm{g}$ BB mencit yang bila dikonversikan kedalam dosis ekstrak daun kersen (Muntingiacalabura l.) sama dengan dosis 3mg/ $20 \mathrm{gBB}^{7}$. Sel ballooning merupakan reversible injury yang dapat diakibatkan oleh radikal bebas sehingga antioksidan dapat menurunkan kerusakan pada sel hepar yang dikarenakan oleh radikal bebas tersebut - Daun kersen sendiri merupakan bagian dari tanaman kersen yang mengandung antioksidan tertinggi. Daun kersen mengandung flavonoid, tanin, dan saponin dapat berperan sebagai antioksidan yang menurunkan kerusakan sel akibat radikal bebas (KrishnaveniMarimuthu, DhanalakshmiRavi, 2014). Flavonoid berperan sebagai antioksidan dengan berbagai cara seperti menurunkan kadar mediator proinflamasi melalui hambatan terhadap nuclearfactor $k B$, mendonorkan ion hidrogen untuk menetralisir efek toksik dari radikal bebas, serta meningkatkan ekspresi gen antioksidan endogen melalui mekanisme aktivasi nuclear erthroid relates factor 2 (Castilla P, Echarri R, Davalos A, Cerrato F, 2006, Anggia S.W.J, 2015).

\section{KESIMPULAN}

Terdapat pengaruh ekstrak daun kersen (Muntingia calabura l.) terhadap gambaran histopatologi hepar pada mencit (Mus musculus) yang diinduksi diet tinggi lemak. Dosis efektif ekstrak daun kersen terhadap perbaikan gambaran histopatologi hepar pada mencit yang diinduksi diet tinggi lemak adalah 1,5mg/20grBB/hari.

\section{DAFTAR PUSTAKA}

McCance KL, Huether SE, Brashers VL, Rote NS, 2010,Pathophysiology; The Biologic Basis for Disease in Adult and Children. 6th ed. USA.

Fatbolcu, Hakan and Zorlu, Elcin, 2016,Nonalcoholic Fatty Liver Disease as a Multi-Systemic Disease, World Journal of Gastroenterology, Vol.22, pp. 4079-4090.

Sutejo I.R, Dewi R, 2012, Kerusakan Sel Hati dan Peningkatan Kolesterol Serum Mencit Akibat Pemberian Minyak Goreng Bekas Pakai, Jurnal IKESMA, vol.8, pp.9-16

Ratziu V, Bellentani S, Cortez-Pinto H, Day C, Marchesini G, 2010,A position statement on NAFLD/NASH based on the EASL 2009 special conference, Journal of Hepatology, vol53, pp.372-384.

Takahashi Y, Fukusato T, 2014, Histopathology of nonalcoholic fatty liver disease / nonalcoholic steatohepatitis, World Journal of Gastroenteroogy,vol.20, no.42, pp. 1553915548

Surjowardojo P, Sarwiyono, Thohari I, Ridhowi A, 2014, Quantitative and Qualitative Phytochemicals Analysis of Muntingia calabura, Journal of Biology, Agriculture and Healthcare, vol.4, pp.84-89

Das N, Sikder K, Ghosh S, Fromenty B, Dey S, 2012, Moringa oleifera Lam. Leaf extract prevents early liver injury and restores antioxidant status in mice fed with high-fat diet, Indian Journal of Experimental Biology, vol50, pp. 404-412

KrishnaveniMarimuthu, DhanalakshmiRavi, 2014, Qualitative and Quantitative Study of Phytochemicals in Muntingiacalabura l. and Fruit, Department of Biochemistry Periyar University, Salem636011, Vol.3, Issue 6, pp. 1687-1696, ISSN $2277-7105$

Ghidurus, M., Turtoi, M., Boskou, G., Niculita, P., Stan, V., 2010, Nutritional and bealth aspects related to frying, Romanian Biotechnological Letters, vol.15,no 6 .

Sartika, R.A.D, 2009, Pengaruh Suhu dan Lama Proses Menggoreng (Deep Frying)Terhadap Pembentukan Asam Lemak Trans, Markara Sains, vol 13, pp23-8

Budiyanto, Zuki Meizul, Hutasoit S. Mina, 2012, Ketabanan Minyak Goreng Kemasan dan Minyak. 
Curah pada Penggorengan Kerupuk Jalin, Bengkulu, Jurnal Agroindustri, Vol.2, No.1, pp. $34-40$

Juluri R, Vuppalanchi R, Olson J, Ünalp A,Van NM, Cummings OW, Tonascia J, Chalasani N, 2011, Generalizability of the NASH CRN Histological Scoring System for Nonalcoholic Fatty Liver Disease, Journal of Clinical Gastroenterology, vol.45, no.1, Jan., pp. 5558

Fan JG, Farrell GC, 2009, Review; Epidemiology of non-alcoholic fatty liver disease in China.Journal of Hepatology, vol.50, pp. 204-210.

Dowman JK, Tomlinson JW, Newsome PN, 2010, Review; Pathogenesis of nonalcoholicfatty liver disease. Q J Med, vol 103, pp. 71-83.

Castilla P, Echarri R, Davalos A, Cerrato F, 2006, Concentreted red grape juice exerts antioxidant, bypolipidemic, and antiinflammastory effects in both bemodiálisis patients and healthy subjects, American Journal of Clinical Nutrition, vol84, pp. 252-62.

Anggia S.W.J, 2015, The effect of ethanol extract os soursop leaves to decreased levels of malondialdehyde, Journal Majority,vol4, no 3,pp.14-18.

Kumar V, Abbas AK, Aster JC, 2015, Robbins and Cotran Pathologic Basis of Disease, $9^{\text {th }}$ Edition, Philadelphia, Elsevier Saunders, pp. 40-41, 62. 